Prive; Volume 3, Nomor 2, September 2020 http://ejurnal.unim.ac.id/index.php/prive

Online ISSN 2615-7314

Printed ISSN $\underline{\text { 2615-7306 }}$

\title{
ANALISIS VARIANS UNTUK MENGUKUR EFISIENSI DAN EFEKTIFITAS ANGGARAN PERUSAHAAN PG GEMPOLKREP TAHUN 2014 - 2015
}

\author{
Budi Utami ${ }^{1}$ \\ Eny Setyariningsih ${ }^{2}$ \\ ${ }^{1,2}$ Fakultas Ekonomi Universitas Islam Majapahit \\ utamiwahjoe@gmail.com ${ }^{1}$
}

\begin{abstract}
The budget functions as an aspect of planning and supervision in the company's operational activities. The budget must be able to adjust the plans made for various parts of the company, so that one activity plan will be in harmony with another. Efficiency is the relationship between goods and services produced by an activity and the resources used. An activity is said to be efficient if it is able to produce certain outputs with the lowest possible input or with certain inputs it is able to produce the maximum output (spending well). Meanwhile, effectiveness is the relationship between the output and the goals or objectives that must be achieved. Operational activities are said to be effective if the activity process achieves the final policy goals and objectives (spending wisely). The purpose of this study was to determine the variance of the sales and production budget of PG. Gempolkrep Mojokerto 2014 - 2015 and measures the level of efficiency and effectiveness of PG's sales and production budget. Gempolkrep Mojokerto 2014 - 2015. The analysis method used is analysis of variance. The results of this study contained unfavorable variances in the sales budget for 2014 and 2015. Production budgets for 2014 and 2015 showed favorable variances. The use of the budget for 2014 and 2015 is less than $80 \%$ or is in the efficient category. The company's budget performance for 2014 - 2015 is in the range of less than $80 \%$ or is in the less effective category.
\end{abstract}

Keywords: sales budget, production budget, analysis of variance, efficiency, effectiveness

\begin{abstract}
Abstrak
Anggaran berfungsi sebagai aspek perencanaan dan pengawasan dalam kegiatan operasional perusahaan. Anggaran harus dapat menyesuaikan rencana yang dibuat untuk berbagai bagian dalam perusahaan, sehingga rencana kegiatan yang satu akan selaras dengan lainnya. Efisiensi adalah hubungan antara barang dan jasa yang dihasilkan sebuah kegiatan dengan sumber daya yang digunakan. Suatu kegiatan dikatakan efisien apabila mampu menghasilkan output tertentu dengan input yang serendahrendahnya atau dengan input tertentu mampu menghasilkan output sebesar-besarnya (spending well). Sedangkan efektivitas merupakan hubungan antara keluaran dengan tujuan atau sasaran yang harus dicapai. Kegiatan operasional dikatakan efektif apabila proses kegiatan mencapai tujuan dan sasaran akhir kebijakan (spending wisely). Tujuan penelitian ini untuk mengetahui varians anggaran penjualan dan produksi PG. Gempolkrep Mojokerto tahun 2014 - 2015 dan mengukur tingkat efisiensi dan efektifitas anggaran penjualan dan produksi PG. Gempolkrep Mojokerto tahun 2014 - 2015. Metode analisa yang digunakan adalah analisis varians. Hasil penelitian ini terdapat varians unfavorable pada anggaran penjualan tahun 2014 dan 2015. Anggaran produksi tahun 2014 dan 2015 menunjukkan varians favorable. Penggunaan anggaran untuk tahun 2014 dan 2015 kurang dari 80\% atau berada pada kategori efisien. Kinerja anggaran perusahaan tahun 2014 - 2015 berada pada range kurang dari $80 \%$ atau berada pada kategori kurang efektif.
\end{abstract}

Kata Kunci: anggaran penjualan, anggaran produksi, analisis varians, efisiensi, efektifitas 


\section{A. PENDAHULUAN}

Peranan anggaran pada suatu perusahaan merupakan alat untuk membantu manajemen dalam pelaksanaan, fungsi perencanaan, koordinasi, pengawasan dan juga sebagai pedoman kerja dalam menjalankan perusahaan untuk tujuan yang telah ditetapkan (Siregar, $2003: 3$ ). Anggaran berfungsi sebagai aspek perencanaan dan pengawasan dalam kegiatan operasional perusahaan. Anggaran harus dapat menyesuaikan rencana yang dibuat untuk berbagai bagian dalam perusahaan, sehingga rencana kegiatan yang satu akan selaras dengan lainnya. Untuk itu anggaran dapat dipakai sebagai alat koordinasi untuk seluruh bagian yang ada dalam perusahaan, karena semua kegiatan yang saling berkaitan antara satu bagian dengan bagian lainnya sudah diatur dengan baik. Sedangkan aspek pengawasan yaitu dengan membandingkan antara prestasi dengan yang dianggarkan, apakah dapat ditemukan efisiensi atau apakah para manajer pelaksana telah bekerja dengan baik dalam mengelola perusahaan.

Biaya standar adalah biaya yang ditentukan di muka, yang merupakan jumlah biaya yang seharusnya dikeluarkan untuk satu satuan produk atau untuk membiayai kegiatan tertentu, di bawah asumsi kondisi ekonomi, efisien dan faktor-faktor lain tertentu (Mulyadi, 1995 : 415). Biaya standar adalah biaya yang telah ditentukan terlebih dahulu (diperkirakan akan taerjadi) dan apabila penyimpangan terhadapnya, maka biaya standar ini dianggap benar (Abdul Halim, 2008 : 9). Sistem biaya standar dirancang untuk mengendalikan biaya. Biaya standar merupakan alat yang penting dalam pelaksanaan kebijakan yang telah ditetapkan sebelumnya. Sistem biaya standar memberikan pedoman kepada manajemen berapa biaya yang seharusnya untuk melaksanakan kegiatan tertentu. Sistem biaya standar menyajikan analisis penyimpangan biaya sesungguhnya dari biaya standar memungkinkan manajemen melaksanakan pengelolaan dengan "prinsip kelainan" (exception principle), yaitu memberikan perhatian terhadap keadaan yang meyimpang dari keadaan yang seharusnya. Sistem biaya standar sama dengan sistem biaya aktual kecuali ditambahkan perkiraan varian. Biaya standar biasanya berbeda dengan biaya yang benar-benar dikeluarkan dan diperkirakan varian merupakan tempat penampungan untuk perbedaan ini (Robert N Anthony dan Roger H. Hermanson, $2001: 40$ ).

Actual Costing ini adalah costing yang secara nyata terjadi. Actual costing hanya dapat dihitung pada akhir periode akuntansi. Oleh karena itu sulit sekali menggunakan actual costing untuk menghitung pembebanan overhead. Manajemen pasti menginginkan informasi biaya dapat cepat diketahui pada setiap aktivitas produksi. Sistem biaya aktual (actual cost system) mengharuskan perusahaan menggunakan biaya aktual dari seluruh sumber daya yang digunakan untuk produksi baik biaya utama maupun biaya overhead untuk menentukan biaya per unit. Biaya utama aktual dapat dibebankan dengan menggunakan penelusuran langsung dan dapat dibebankan secara tepat waktu, sehingga tidak terdapat masalah yang cukup signifikan baik dari segi keakuratan maupun ketepatan waktu. Metode ini mempunyai kelemahan dalam penggunaan biaya aktual untuk perhitungan biaya per unit untuk biaya overhead. Pembebanan biaya overhead aktual menciptakan konflik antara ketepatan waktu dan keakuratan.

Efisiensi adalah hubungan antara barang dan jasa yang dihasilkan sebuah kegiatan atau aktifitas dengan sumber daya yang digunakan. Suatu organisasi, kegiatan atau program dikatakan efisien apabila mampu menghasilkan output tertentu dengan input serendahrendahnya atau dengan input tertentu mampu menghasilkan output sebesar-besarnya (spending well). Dari pengertian dapat disimpulkan bahwa efisiensi adalah hubungan antara barang dan jasa (output) yang dihasilkan dari sebuah kegiatan atau aktivitas dengan sumber daya (input) yang digunakan dengan tidak membuang waktu, tenaga dan biaya dengan percuma Deddi dan Ayuningtyas (2010: 161). Suatu kegiatan dikatakan telah dikerjakan secara efisien jika pelaksanaan pekerjaan tersebut telah mencapai sasaran (output) dengan biaya (input) yang terendah / dengan biaya (input) minimal diperoleh hasil (output) yang diinginkan.

Efektivitas pada dasarnya berhubungan dengan pencapaian tujuan atau target kebijakan (hasil guna). Ihyaul (2009: 26) efektivitas merupakan hubungan antara keluaran dengan tujuan atau sasaran yang harus dicapai. Kegiatan operasional dikatakan efektif apabila proses kegiatan mencapai tujuan dan sasaran akhir kebijakan (spending wisely). Indikator efektivitas menggambarkan jangkauana akibat dan dampak (outcome) dari keluaran atau output program dalam mencapai tujuan program. Semakin besar kontribusi output pada pencapaian tujuan, maka semakin efektif organisasi, program, atau kegiatan. Dari beberapa pengertian efektivitas 
diatas dapat disimpulkan bahwa efektivitas adalah kesuksesan atau kegagalan antara keluaran dengan tujuan atau sasaran yang harus dicapai.

Pabrik Gula Gempolkerep adalah sebuah pabrik gula yang dalam produksinya menghasilkan gula jenis SHS dengan hasil sampingan yang berupa tetes. Di dalam proses produksinya tersebut pabrik Gula Gempolkerep menggunakan beberapa tahapan dalam memproses tebu menjadi gula pasir, yaitu tahapan gilingan, pemurnian, penguapan, kristalisasi, puteran dan penyelesaian. Dengan banyaknya tahapan / proses dalam membuat tebu menjadi gula pasir maka diperlukan perencanaan, koordinasi dan pengawasan biaya aktual dan biaya standar terhadap kegiatan produksi. Pengukuran efisiensi dan efektifitas biaya standar dan biaya aktual dibatasi pada anggaran produksi dan anggaran penjualan saja. Tujuan dari penelitian ini adalah untuk mengetahui varians anggaran penjualan dan produksi PG. Gempolkrep Mojokerto tahun 2014 - 2015 dan mengukur tingkat efisiensi dan efektifitas anggaran penjualan dan produksi PG. Gempolkrep Mojokerto tahun 2014 - 2015. Sehingga peneliti tertarik untuk melakukan riset dengan judul "ANALISIS VARIANS UNTUK MENGUKUR EFISIENSI DAN EFEKTIFITAS ANGGARAN PERUSAHAAN PG GEMPOLKREP TAHUN 2014 - 2015"

\section{B. KAJIAN TEORI}

Anggaran adalah rencana tertulis mengenali kegiatan suatu organisasi yang dinyatakan secara kuantitatif dan umumnya dinyatakan dalam satuan uang untuk jangka waktu tertentu (M. Nafarin, 2004:12). Peranan anggaran pada suatu perusahaan merupakan alat untuk membantu manajemen dalam pelaksanaan, fungsi perencanaan, koordinasi, pengawasan dan juga sebagai pedoman kerja dalam menjalankan perusahaan untuk tujuan yang telah ditetapkan (Siregar, $2003: 3$ ).

1) Fungsi Perencanaan

Perencanaan merupakan salah satu fungsi manajemen dan fungsi ini merupakan salah satu fungsi manajemen dan fungsi ini merupakan dasar pelaksanaan fungsi-fungsi manajemen lainnya. Sebelum perusahaan melakukan operasinya, pimpinan dari perusahaan tersebut harus lebih dahulu merumuskan kegiatan-kegiatan apa yang akan dilaksanakan di masa datang dan hasil yang akan dicapai dari kegiatan-kegiatan tersebut, serta bagaimana melaksanakannya. Dengan adanya rencana tersebut, maka aktifitas akan dapat terlaksana dengan baik.

2) Fungsi Pengawasan

Anggaran merupakan salah satu cara mengadakan pengawasan dalam perusahaan. Pengawasan itu merupakan usaha-usaha yang ditempuh agar rencana yang telah disusun sebelurnnya dapat dicapai. Dengan demikian pengawasan adalah mengevaluasi prestasi kerja dan tindakan perbaikan apabila perlu. Aspek pengawasan yaitu dengan membandingkan antara prestasi dengan yang dianggarkan, apakah dapat ditemukan efisiensi atau apakah para manajer pelaksana telah bekerja dengan baik dalam mengelola perusahaan.

3) Fungsi Koordinasi

Fungsi koordinasi menuntut adanya keselarasan tindakan bekerja dari setiap individu atau bagian dalam perusahaan untuk mencapai tujuan. Dengan demikian dapat dikatakan bahwa untuk menciptakan adanya koordinasi diperlukan perencanaan yang baik, yang dapat menunjukkan keselarasan rencana antara satu bagian dengan bagian lainnya.

4) Anggaran Sebagai Pedoman Kerja

Anggaran merupakan suatu rencana kerja yang disusun sistematis dan dinyatakan dalam unit moneter. Lazimnya penyusunan anggaran berdasarkan pengalaman masa lalu dan taksirtaksiran pada masa yang akan datang, maka ini dapat menjadi pedoman kerja bagi setiap bagian dalam perusahaan untuk menjalankan kegiatannya

Biaya standar adalah biaya yang ditentukan di muka, yang merupakan jumlah biaya yang seharusnya dikeluarkan untuk satu satuan produk atau untuk membiayai kegiatan tertentu, di bawah asumsi kondisi ekonomi, efisien dan faktor-faktor lain tertentu (Mulyadi, 2008 : 415). Sistem biaya standar memberikan pedoman kepada manajemen berapa biaya yang seharusnya untuk melaksanakan kegiatan tertentu. Sistem biaya standar menyajikan analisis penyimpangan biaya sesungguhnya dari biaya standar memungkinkan manajemen 
melaksanakan pengelolaan mereka dengan "prinsip kelainan" (Excception principle). Dengan memusatkan perhatian mereka terhadap keadaan yang meyimpang dari keadaan yang seharusnya, manajemen dilengkapi dengan alat yang efektif untuk mengendalikan kegiatan perusahaan. Mulyadi (2009 : 388). Biaya standar membantu perencanaan dan pengendalian operasi. Biaya standar memberikan wawasan mengenai dampak-dampak yang mungkin dari keputusan atas biaya dan laba. Biaya standar digunakan untuk:

1) Menetapkan anggaran

2) Mengendalikan biaya dengan cara memotivasi karyawan dan mengukur efisiensi operasi.

3) Menyederhanakan prosedur perhitungan biaya dan mempercepat laporan keuangan.

4) Membebankan persediaan bahan baku, barang dalam proses dan barang jadi.

5) Menetapkan tawaran kontrak dan harga jual.

Actual Costing ini adalah costing yang secara nyata terjadi. Actual costing hanya dapat dihitung pada akhir periode akuntansi. Oleh karena itu sulit sekali menggunakan Actual Costing untuk menghitung pembebanan overhead. Sistem biaya aktual (actual cost system) mengharuskan perusahaan menggunakan biaya aktual dari seluruh sumber daya yang digunakan untuk produksi baik biaya utama maupun biaya overhead untuk menentukan biaya per unit. Biaya utama aktual dapat dibebankan dengan menggunakan penelusuran langsung dan dapat dibebankan secara tepat waktu, sehingga tidak terdapat masalah yang cukup signifikan baik dari segi keakuratan maupun ketepatan waktu.

Deddi dan Ayuningtyas (2010: 161) efisiensi adalah hubungan antara barang dan jasa yang dihasilkan sebuah kegiatan atau aktifitas dengan sumber daya yang digunakan. Suatu organisasi, kegiatan atau program dikatakan efisien apabila mampu menghasilkan output tertentu dengan input serendah-rendahnya, atau dengan input tertentu mampu menghasilkan output sebesar-besarnya (spending well). Efisiensi juga mengandung beberapa pengertian antara lain; (1) efisiensi pada sektor usaha swasta (private sector efficiency), dijelaskan dengan konsep input output yaitu rasio output dan input (2) efisiensi pada sektor pelayanan masyarakat (public sector efficiency) adalah suatu kegiatan yang dilakukan dengan baik dengan pengorbanan seminimal mungkin (3) Suatu kegiatan dikatakan telah dikerjakan secara efisien jika pelaksanaan pekerjaan tersebut telah mencapai sasaran (output) dengan biaya (input) yang terendah atau dengan biaya (input) minimal diperoleh hasil (output) yang diinginkan.51

Efektivitas adalah pemanfaatan sumber daya, sarana dan prasarana dalam jumlah tertentu yang secara sadar ditetapkan sebelumnya untuk menghasilkan sejumlah barang atas jasa kegiatan yang dijalankannya (Sondang, 2001 : 24). Mardiasmo (2009:132) efektifitas pada dasarnya berhubungan dengan pencapaian tujuan atau target kebijakan (hasil guna). Efektifitas merupakan hubungan antara keluaran dengan tujuan atau sasaran yang harus dicapai. Kegiatan operasional dikatakan efektif apabila proses kegiatan mencapai tujuan dan sasaran akhir kebijakan (spending wisely). Menurut Abdurahmat (2003:92) efektivitas adalah pemanfaatan sumber daya, sarana dan prasarana dalam jumlah tertentu yang secara sadar ditetapkan sebelumnya untuk menghasilkan sejumlah pekerjaan tepat pada waktunya.

\section{METODE PENELITIAN}

Desain penelitian ini adalah penelitian kuantitatif deskriptif. Penelitian ini menggunakan data sekunder yaitu data tentang biaya penjualan dan biaya produksi PG. Gempolkrep Mojokerto tahun 2014 - 2015. Teknik analisis data yang dilakukan dalam penelitian ini adalah analisis varians dengan teknik pengumpulan data library research.

Rumus menganalisis tingkat efisiensi dalam pengelolaan keuangan dengan melihat perbandingan antara realisasi anggaran biaya dengan realisasi pendapatan sebagai berikut :

Efisiensi $=\frac{\text { Realisasi Biaya }}{\text { Realisasi Pendapatan }} * 100 \%$

Kriteria untuk mengukur tingkat efisiensi adalah sebagai berikut :

1. Lebih dari $100 \% \quad$ : tidak efisien

2. Antara $90 \%-100 \%$ : kurang efisien 
3. Antara $80 \%-90 \%$ : cukup efisien

4. Antara $60 \%-80 \%$ : efisien

5. Dibawah $60 \%$ : sangat efisien

Rumus menganalisis efektivitas dapat dilihat dari perbandingan antara realisasi biaya dan target biaya yaitu sebagai berikut :

Efektivitas $=\frac{\text { Realisasi Biaya }}{\text { Target Biaya } \quad \mathrm{x} 100 \%}$

Kriteria penilaian dan kinerja dapat diketahui dengan melihat kriteria sebagai berikut :

1. Hasil perbandingan diatas $100 \%$ berarti sangat efektif

2. Hasil perbandingan antara $90 \%-100 \%$ berarti efektif

3. Hasil perbandingan antara $80 \%-90 \%$ berarti cukup efektif

4. Hasil perbandingan $60 \%-80 \%$ berarti kurang efektif

5. Hasil perbandingan dibawah $60 \%$ berarti tidak efektif

\section{HASIL DAN PEMBAHASAN}

a. Anggaran Penjualan Tahun 2014

Tabel 1

Varians Anggaran Penjualan PG. Gempolkrep Mojokerto

tahun 2014

\begin{tabular}{|c|c|c|c|c|c|}
\hline Keterangan & Anggaran & Realisasi & & Varian & Ket \\
\hline \multicolumn{6}{|l|}{ Gula } \\
\hline \multicolumn{6}{|l|}{ Penjualan eks tahun ini : } \\
\hline Harga / ton & Rp. $\quad 8.486 .291$ & Rp. & Rp. & 1.229 .670 & \\
\hline Total harga & Rp. 246.202 .919 & 7.256 .621 & Rp. & 74.877 .005 & (UF) \\
\hline Penjualan eks tahun lalu & & Rp. & & & \\
\hline Harga / ton & Rp. & 171.325 .914 & Rp. & 7.559 .269 & \\
\hline Total harga & Rp. & & Rp. & 718.123 & \\
\hline \multirow[t]{6}{*}{ Jumlah } & Rp. 246.202.919 & Rp. & Rp. & 74.158 .882 & (UF) \\
\hline & & 7.559 .269 & & & \\
\hline & & Rp. & & & \\
\hline & & 718.123 & & & \\
\hline & & Rp. & & & \\
\hline & & 172.044 .037 & & & \\
\hline \multicolumn{6}{|l|}{ Tetes } \\
\hline \multicolumn{6}{|l|}{ Penjualan eks tahun ini : } \\
\hline Harga / ton & Rp. $\quad 1.000 .000$ & Rp. & Rp. & 516.577 & \\
\hline Total harga & Rp. 26.812 .500 & 1.516 .577 & Rp. & 12.915 .584 & $\mathrm{~F}$ \\
\hline Penjualan eks tahun lalu: & & Rp. & & & \\
\hline Harga / ton & Rp. & 39.728 .084 & Rp. & 902.316 & \\
\hline Total harga & Rp. $\quad 0$ & & Rp. & 4.000 .615 & \\
\hline \multirow{6}{*}{ Jumlah } & Rp. 26.812 .500 & Rp. & Rp. & 16.916 .199 & $\mathrm{~F}$ \\
\hline & & 902.316 & & & \\
\hline & & Rp. & & & \\
\hline & & 4.000 .615 & & & \\
\hline & & Rp. & & & \\
\hline & & 43.728 .699 & & & \\
\hline JUMLAH & Rp. 273.015.419 & Rp. & Rp. & 57.242 .683 & (UF) \\
\hline & & 215.772 .736 & & & \\
\hline
\end{tabular}

Sumber : Data sekunder diolah, 2020

Dari tabel 1 diatas, diketahui bahwa terdapat varians unfavorable dari penjualan gula tahun 2014, karena realisasi penjualan lebih rendah dari anggaran yaitu sebesar Rp 74.877.005. Sisa penjualan gula tahun sebelumnya jika diakumulasaikan dengan penjualan tahun 2014 menunjukkan peningkatan dari Rp 171.325.914 menjadi Rp 172.044.037 tetapi tetap belum 
bisa menutup varians yang cukup besar Rp 74.158.882. Penjualan side product dari gula yaitu tetes tebu menunjukkan varians menguntungkan / favorable yang cukup besar antara anggaran dan realisasinya sebesar Rp 12.915.584. Penjualan tetes tebu tahun 2014 Rp 39.728.084 jika diakumulasaikan dengan penjualan tahun sebelumnya menjadi $\mathrm{Rp} 43.728 .699$ dengan varians favorable sebesar $\mathrm{Rp} \mathrm{16.916.199.} \mathrm{Tetapi} \mathrm{secara} \mathrm{keseluruhan} \mathrm{anggaran} \mathrm{penjualan} \mathrm{gula} \mathrm{dan} \mathrm{tetes}$ tahun 2014 unfavorable karena realisasi penjualan lebih rendah dari anggaran dengan varians sebesar 57.242.683.

\section{b. Anggaran Penjualan Tahun 2015}

Tabel 2

Varians Anggaran Penjualan PG. Gempolkrep Mojokerto tahun 2015

\begin{tabular}{|c|c|c|c|c|}
\hline Keterangan & Anggaran & Realisasi & Varian & Ket \\
\hline \multicolumn{5}{|l|}{ Gula } \\
\hline \multicolumn{5}{|l|}{ Penjualan eks tahun ini : } \\
\hline Harga / ton & Rp. $\quad 7.898 .352$ & Rp. $\quad 8.833 .632$ & 935.280 & \\
\hline Total harga & Rp. 232.059.571 & Rp. 131.173 .510 & Rp. 100.886.061 & (UF) \\
\hline \multicolumn{5}{|l|}{ Penjualan eks tahun lalu : } \\
\hline Harga / ton & Rp. & Rp. $\quad 7.037 .137$ & Rp. $\quad 7.037 .137$ & \\
\hline Total harga & Rp. & Rp. $\quad 14.382 .296$ & Rp. 14.382 .296 & \\
\hline Jumlah & Rp. 232.059.571 & Rp. 145.555 .806 & Rp. 86.503 .765 & (UF) \\
\hline \multicolumn{5}{|l|}{ Tetes } \\
\hline \multicolumn{5}{|l|}{ Penjualan eks tahun ini : } \\
\hline Harga / ton & Rp. $\quad 1.300 .000$ & Rp. $\quad 1.816 .810$ & Rp. $\quad 516.810$ & \\
\hline Total harga & Rp. 20.913 .750 & Rp. $\quad 46.132 .976$ & Rp. 25.219 .226 & $\mathrm{~F}$ \\
\hline \multicolumn{5}{|l|}{ Penjualan eks tahun lalu : } \\
\hline Harga / ton & Rp. & 1.290 .056 & 1.290 .056 & \\
\hline Total harga & Rp. $\quad 0$ & Rp. $\quad 7.002 .980$ & Rp. $\quad 7.002 .980$ & \\
\hline Jumlah & Rp. 20.913 .750 & Rp. $\quad 53.135 .956$ & Rp. 32.222 .206 & $\mathrm{~F}$ \\
\hline JUMLAH & Rp. 252.973.321 & Rp. 198.691 .762 & Rp. 54.281 .559 & (UF) \\
\hline
\end{tabular}

Sumber : Data sekunder diolah, 2020

Dari tabel 2 diatas, diketahui bahwa terdapat varians unfavorable dari penjualan gula tahun 2015, karena realisasi penjualan lebih rendah dari anggaran yaitu sebesar Rp 100.886.061 realisasi penjualan gula tahun 2015 jika diakumulasaikan dengan penjualan tahun 2014 menunjukkan peningkatan dari Rp 131.173.510 menjadi Rp 145.555.806. tetapi belum bisa menutup varians penjualan yang cukup besar Rp 86.503.765.

Penjualan side product dari gula yaitu tetes tebu menunjukkan varians menguntungkan / favorable yang cukup besar antara anggaran dan realisasinya sebesar Rp 25.219.226. Penjualan tetes tebu tahun $2015 \mathrm{Rp} 46.132 .976$ jika diakumulasaikan dengan penjualan tahun sebelumnya yaitu tahun 2014 menjadi Rp.53.135.956 dengan varians favorable sebesar Rp 32.222.206. Tetapi secara keseluruhan anggaran penjualan gula dan tetes tahun 2015 bisa dikatakan unfavorable karena realisasi penjualan lebih rendah dari anggaran sebesar 54.281.559.

Tabel 1 dan 2 menunjukkan varians unfavorable, artinya bahwa perusahaan sebenarnya tidak dalam keadaan merugi tetapi merujuk pada kinerja perusahaan yang belum bisa mencapai target yang telah ditetapkan. Hal ini bisa disebabkan oleh banyak faktor, baik faktor internal maupun faktor eksternal. Faktor-faktor internal tersebut antara lain kualitas produkyang dihasilkan, kemampuan perusahaan dalam memenuhi pasar dan harga jual. Sedangkan faktor eksternal berupa banyaknya pilihan produk gula di pasaran dengan kualitas yang lebih baik dan harga yang kompetitif. Varians unfavorable ini tidak boleh dibiarkan berlarut-larut karena akan menyebabkan perusahaan kehilangan kesempatan untuk mendapatkan laba, seperti tampak pada tabel 1 dan tabel 2 dimana penjualan 2014 dan 2015 belum bisa memenuhi target yang ditetapkan. 


\section{c. Anggaran Produksi Tahun 2014}

Tabel 3

Varians Anggaran Produksi PG. Gempolkrep Mojokerto tahun 2014

\begin{tabular}{|c|c|c|c|c|}
\hline Keterangan & Anggaran & Realisasi & Varian & Ket \\
\hline \multicolumn{5}{|l|}{ Gula } \\
\hline Pimpinan dan tata usaha & Rp. 13.141 .051 & 12.528 .795 & Rp. $\quad 612.256$ & \\
\hline Penyusutan aktiva benda & Rp. 31.504 .977 & Rp. & Rp. 31.504 .977 & \\
\hline Pembibitan & (Rp. 111.955) & (Rp. & Rp. $\quad 51.656$ & \\
\hline Tebu giling & Rp. 15.706 .409 & 60.299) & Rp. 3.095 .040 & \\
\hline Tebang dan angkut tebu & Rp. 15.496 .878 & Rp. 12.611 .369 & Rp. 5.491 .538 & \\
\hline Pabrik & Rp. $\quad 54.500 .995$ & Rp. $\quad 10.005 .340$ & Rp. 7.789 .761 & \\
\hline Pengelolahan & Rp. 30.443 .934 & Rp. $\quad 46.711 .234$ & Rp. 8.047 .745 & \\
\hline Pengemasan & Rp. $\quad 5.521 .462$ & 22.396 .189 & Rp. 2.845 .716 & \\
\hline Quality Control (QC) & Rp. $\quad 7.598 .143$ & 2.675 .745 & Rp. 3.434 .401 & \\
\hline \multirow[t]{2}{*}{ Jumlah } & Rp. 173.801 .894 & Rp. $\quad 4.163 .742$ & Rp. 62.769 .709 & $\mathrm{~F}$ \\
\hline & & Rp. 111.032.185 & & \\
\hline \multicolumn{5}{|l|}{ Tetes } \\
\hline Pimpinan dan tata usaha & Rp. $\quad 1.461 .740$ & 2.925 .497 & Rp. 1.463 .757 & \\
\hline Penyusutan aktiva benda & Rp. $\quad 3.504 .443$ & $\mathrm{Rp}$. & Rp. 3.504 .443 & \\
\hline Pembibitan & (Rp. 12.453) & (Rp. & Rp. $\quad 1.610$ & \\
\hline Tebu giling & Rp. $\quad 1.747 .096$ & $14.063)$ & Rp. 1.197 .683 & \\
\hline Tebang dan angkut tebu & Rp. $\quad 1.723 .788$ & Rp. $\quad 2.944 .779$ & Rp. $\quad 612.478$ & \\
\hline Pabrik & 6.062 .395 & 2.336 .266 & Rp. $\quad 4.844 .768$ & \\
\hline Pengelolahan & Rp. $\quad 3.386 .418$ & Rp. $\quad 10.907 .163$ & Rp. 1.843 .136 & \\
\hline Pembibitan tetes milik PTR & Rp. & 5.229 .554 & Rp. $\quad 0$ & \\
\hline Quality Control (QC) & Rp. $\quad 845.176$ & Rp. & 127.066 & \\
\hline \multirow[t]{2}{*}{ Jumlah } & Rp. 18.718 .603 & 972.242 & Rp. $\quad 6.582 .835$ & (UF) \\
\hline & & Rp. $\quad 25.301 .438$ & & \\
\hline JUMLAH & Rp. 192.520 .497 & Rp. 136.333 .623 & Rp. 56.186.874 & $\mathrm{F}$ \\
\hline
\end{tabular}

Sumber : Data sekunder diolah, 2020

Tabel 3 merupakan data antara anggaran dan realisasi produksi gula dan tetes tebu tahun 2014. Dari data tabel diatas diketahui bahwa realisasi biaya produksi gula $\mathrm{Rp} 111.032 .185$ lebih rendah dari biaya yang dianggarkan $\mathrm{Rp} 173.801 .894$ sehingga terdapat selisih favorable sebesar Rp 62.769.709, dimana hal ini merupakan varians yang menguntungkan. Sedangkan realisasi biaya produksi tetes tebu sebesar $\mathrm{Rp} 25.301 .438$ ternyata lebih tinggi $\mathrm{Rp}$ (6.582.835) dari anggarannya yang sebesar $\mathrm{Rp} 18.718 .603$ dimana hal ini menunjukkan varians unfavorable. Secara keseluruhan anggaran produksi tahun 2014 menunjukkan varians favorable sebesar Rp 56.186.874 karena total realisasi biaya produksi Rp 136.333.623 lebih rendah daripada biaya produksi yang dianggarkan sebesar Rp 192.520.497.

\section{d. Anggaran Produksi Tahun 2015}

Tabel 4

Varians Anggaran Produksi PG. Gempolkrep Mojokerto tahun 2015

\begin{tabular}{|c|c|c|c|c|}
\hline Keterangan & Anggaran & Realisasi & Varian & Ket \\
\hline \multicolumn{5}{|l|}{ Gula } \\
\hline Pimpinan dan tata usaha & Rp. 12.567 .715 & Rp. 10.789.887 & Rp. 17.77.828 & \\
\hline Penyusutan aktiva benda & Rp. 34.818 .759 & Rp. 21.194.725 & Rp. 13.624.034 & \\
\hline Pembibitan & (Rp. & Rp. 24.994 & Rp. 142.559 & \\
\hline Tebu giling & 167.553) & Rp. 9.551 .902 & Rp. 6.406 .109 & \\
\hline Tebang dan angkut tebu & Rp. 15.958 .011 & Rp. 7.751 .760 & Rp. 5.427.291 & \\
\hline Pabrik & Rp. 13.179 .051 & Rp. 32.028 .336 & Rp. 28.108.008 & \\
\hline Pengelolahan & Rp. 42.842 .368 & Rp. 14.734 .360 & Rp. 7.765.811 & \\
\hline Pengemasan & Rp. 22.500 .171 & Rp. 2.695.779 & Rp. 345.720 & \\
\hline Quality Control (QC) & Rp. $\quad 3.041 .499$ & Rp. 4.117.888 & Rp. 2.138.945 & \\
\hline Jumlah & $\begin{array}{lr}\text { Rp. } & 6.256 .833 \\
\text { Rp. } 150.996 .854\end{array}$ & Rp. 102.889.631 & Rp. 48.107.223 & $\mathrm{F}$ \\
\hline \multicolumn{5}{|l|}{ Tetes } \\
\hline Pimpinan dan tata usaha & Rp. 1.148 .005 & 2.963 .953 & Rp. 1.815 .948 & \\
\hline Penyusutan aktiva benda & Rp. $\quad 3.180 .541$ & 5.822 .113 & Rp. 2.641 .572 & \\
\hline Pembibitan & (Rp. & 6.866 & 8.439 & \\
\hline Tebu giling & $15.305)$ & 2.623 .881 & Rp. 1.166 .187 & \\
\hline Tebang dan angkut tebu & Rp. 1.457 .694 & 2.129 .387 & Rp. $\quad 925.538$ & \\
\hline
\end{tabular}




\begin{tabular}{llrlrlrr}
\hline Pabrik & Rp. & 1.203 .849 & Rp. 8.798 .095 & Rp. & 4.884 .632 \\
Pengelolahan & Rp. & 3.913 .463 & Rp. 4.047 .488 & Rp. & 1.992 .196 & \\
Pembibitan tetes milik PTR & Rp. & 2.055 .292 & Rp. & 0 & Rp. & 0 & \\
Quality Control (QC) & Rp. & 0 & Rp. 1.131 .173 & Rp. & 559.638 & \\
Jumlah & Rp. & 571.535 & Rp. 27.522 .946 & Rp. 14.007 .872 & (UF) \\
& Rp. 13.515 .074 & & & & & \\
\hline \multicolumn{1}{c}{ JUMLAH } & Rp. 164.511.928 & Rp. 130.412.577 & Rp. 34.099.351 & (F) \\
\hline
\end{tabular}

Sumber : Data diolah peneliti, 2020

Tabel 4 merupakan data antara anggaran dan realisasi produksi gula dan tetes tebu tahun 2015. Dari data tabel diatas diketahui bahwa realisasi biaya produksi gula Rp 102.889.631 lebih rendah dari biaya yang dianggarkan Rp 150.996.854 sehingga terdapat selisih favorable sebesar Rp 48.107.223, dimana hal ini merupakan varians yang menguntungkan. Sedangkan realisasi biaya produksi tetes tebu sebesar Rp 27.522.946 ternyata lebih tinggi Rp (14.007.872) dari anggarannya yang sebesar $\mathrm{Rp}$ 13.515.074 dimana hal ini menunjukkan varians unfavorable. Secara keseluruhan anggaran produksi tahun 2015 menunjukkan varians favorable sebesar Rp 34.099.351 karena total realisasi biaya produksi $\mathrm{Rp} 130.412 .577$ lebih rendah daripada biaya produksi yang dianggarkan sebesar Rp 164.511.928.

\section{e. Efisiensi Anggaran PG. Gempolkrep Mojokerto Tahun 2014-2015}

Untuk menganalisis tingkat efisiensi dalam pengelolaan keuangan dengan melihat perbandingan antara realisasi anggaran biaya dengan realisasi pendapatan sebagai berikut :

Tabel 6

Tingkat Efisiensi Penggunaan Anggaran Perusahaan PG. Gempolkrep Mojokerto

\begin{tabular}{clccc}
\hline Tahun & Biaya $(\mathrm{Rp})$ & Pendapatan $(\mathrm{Rp})$ & Tingkat Efisiensi & Kriteria \\
\hline 2014 & 136.333 .623 & 215.772 .736 & 63,18 & Efisien \\
\hline 2015 & 130.412 .577 & 198.691 .762 & 65,63 & Efisien \\
\hline
\end{tabular}

Sumber : Data diolah peneliti, 2020

Selama periode anggaran tahun 2014 - 2015, tingkat efisiensi anggaran perusahaan berfluktuasi dari tahun ke tahun. Pada tahun 2014 tingkat efisiensi sebesar 63,18\% dan mengalami peningkatan di tahun 2015 sebesar 2,45\% menjadi 65,63\%. Secara keseluruhan penggunaan anggaran untuk tahun 2014 dan 2015 berada pada kategori efisien, artinya dalam kegiatan operasionalnya perusahaan dapat menghasilkan output yang sebesar-besarnya dengan input serendah-rendahnya dengan tidak membuang waktu, tenaga dan biaya dengan percuma (spending well). Dalam menghitung tingkat efisiensi, hanya berpatokan pada hal biaya.

Dimana, efisiensi hanya akan ditentukan oleh ketepatan didalam mendayagunakan anggaran perusahaan dengan memberikan prioritas pada faktor-faktor input yang dapat mengacu pencapaian tujuan. Dalam laporan realisasi anggaran perusahaan PG. Gempolkrep Mojokerto, faktor-faktor input yang dapat mengacu pencapaian tujuan dimasukkan dalam anggaran biaya standar. Dimana ada beberapa kegiatan yang dianggarkan dan masuk dalam anggaran biaya aktual.

\section{f. Efektivitas Anggaran PG. Gempolkrep Mojokerto Tahun 2014-2015}

Untuk menganalisis efektivitas dapat dilihat dari perbandingan antara realisasi biaya dan target biaya yaitu sebagai berikut : 
Tabel 7

Tingkat Efektifitas Anggaran Penjualan PG. Gempolkrep Mojokerto

\begin{tabular}{clcccc}
\hline $\begin{array}{c}\text { Tahu } \\
\mathrm{n}\end{array}$ & Biaya & Standar (Rp) & Aktual (Rp) & $\begin{array}{c}\text { Tingkat } \\
\text { Efektifita } \\
\mathrm{s}\end{array}$ & Kriteria \\
\hline 2014 & $\begin{array}{l}\text { Penjuala } \\
\mathrm{n}\end{array}$ & 273.015 .413 & 215.772 .736 & 79,03 & Kurang Efektif \\
\hline 2015 & $\begin{array}{l}\text { Penjuala } \\
\mathrm{n}\end{array}$ & 252.973 .321 & 198.691 .762 & 78,54 & Kurang Efektif \\
\hline
\end{tabular}

Sumber : Data diolah peneliti, 2020

Selama periode anggaran tahun 2014 - 2015, tingkat efektifitas anggaran penjualan perusahaan berfluktuasi dari tahun ke tahun. Pada tahun 2014 tingkat efektifitas sebesar 79,03\% dan mengalami penurunan sebesar $0,49 \%$ pada tahun 2015 sehingga menjadi 78,54\%. Secara keseluruhan efektifitas anggaran penjualan kurang dari $80 \%$ atau berada dalam range kurang efektif.

Tabel 8

Tingkat Efektifitas Anggaran Produksi

PG. Gempolkrep Mojokerto

\begin{tabular}{cccccc}
\hline $\begin{array}{c}\text { Tahu } \\
\mathrm{n}\end{array}$ & Biaya & Standar (Rp) & Aktual (Rp) & $\begin{array}{c}\text { Tingkat } \\
\text { Efektifita } \\
\text { s }\end{array}$ & Kriteria \\
\hline 2014 & Produksi & 192.520 .497 & 136.333 .623 & 70,80 & Kurang Efektif \\
\hline 2015 & Produksi & 164.511 .928 & 130.412 .577 & 79,27 & Kurang Efektif \\
\hline
\end{tabular}

Sumber : Data diolah peneliti, 2020

Selama periode anggaran tahun 2014 - 2015, tingkat efektifitas anggaran produksi perusahaan berfluktuasi dari tahun ke tahun. Pada tahun 2014 tingkat efektifitas sebesar 70,80\% dan mengalami peningkatan di tahun 2015 sebesar 8,47\% sehingga menjadi 79,27\%. Secara keseluruhan efektifitas anggaran produksi kurang dari $80 \%$ atau berada dalam range kurang efektif.

Pada tabel 7 dan tabel 8 dapat dilihat jika anggaran penjualan dan angaran produksi berada pada range kurang dari $80 \%$ atau beraada dalam kategori kurang efektif. Hal ini disebabkan biaya aktual perusahaan lebih kecil dari target anggaran biaya standar. Kegiatan operasional dikatakan efektif apabila proses kegiatan mencapai tujuan dan sasaran akhir kebijakan (spending wisely). PG. Gempolkrep Mojokerto menilai, ketika kegiatan perusahaan sudah terealisasi dan sesuai dengan yang diharapkan, maka kegiatan tersebut dikatakan efektif.

\section{E. SIMPULAN DAN SARAN}

a. Simpulan

1. Berdasarkan analisis varians, maka anggaran penjualan perusahaan PG. Gempolkrep Mojokerto tahun 2014 - 2015 menunjukkan varians unfavorable, artinya bahwa perusahaan sebenarnya tidak dalam keadaan merugi tetapi merujuk pada kinerja perusahaan yang belum bisa mencapai target yang telah ditetapkan.

2. Berdasarkan analisis varians, maka anggaran produksi perusahaan PG. Gempolkrep Mojokerto tahun 2014 - 2015 menunjukkan varians favorable sebesar karena total realisasi biaya produksi lebih rendah daripada biaya produksi yang telah dianggarkan.

3. Penggunaan anggaran untuk tahun 2014 dan 2015 berada pada range 60\% - 80\% atau berada pada kategori efisien artinya dalam melakukan kegiatan operasionalnya perusahaan telah spending well.

4. Anggaran perusahaan tahun 2014 - 2015 berada pada range kurang dari $80 \%$ atau berada pada kategori kurang efektif karena biaya aktual memiliki perbedaan yang jauh dengan biaya standar yang telah ditetapkan. 


\section{b. Saran}

1. Manajer Keuangan perusahaan PG. Gempolkrep Mojokerto sebaiknya memperhatikan bagaimana Rencana Kegiatan Anggaran Perusahaan

(RKAP) yang dibuat dapat dinilai efektifitas dan efisiensinya sehingga dapat digunakan untuk evaluasi Rencana Kegiatan Anggaran Perusahaan (RKAP) periode berikutnya.

2. Hendaknya perusahaan PG. Gempolkrep berusaha menganalisa berbagai faktor dalam menentukan Rencana Kegiatan Anggaran perusahaan yang akan datang agar dapat meningkatkan dari cukup efisien menjadi efisien dan cukup efektif menjadi efektif.

Hendaknya peneliti selanjutnya menjadikan hasil penelitian ini sebagai acuan serta tambahan referensi untuk mengembangkan penelitian sejenis dengan variabel lain dalam menentukan efisiensi dan efektivitas anggaran perusahaan.

\section{DAFTAR RUJUKAN}

Abdul Halim. 2008. Dasar-dasar Akuntansi Biaya, Edisi 3. Yogyakarta : Penerbit BPFE.

Abdurahmat. 2003. Pengertian Tentang Efektifitas. http://othenk.blogspot.com. Diakses tanggal 25 September 2016.

Ariel Sharon Sumenge. 2013. Analisis Efektifitas dan Efisiensi Pelaksanaan Anggaran Belanja Badan Perencanaan Pembangunan Daerah (BAPPEDA) Minahasa Selatan. Manado : Fakultas Ekonomi Universitas Sam Ratulangi.

Bastian Bustani dan Nurlela. 2009. Akuntansi Biaya : Kajian Teori dan Aplikasi, Edisi Kesatu. Jakarta : Mitra Wacana Media.

Christina, E.,et al. 2001. Anggaran Perusahaan. Jakarta : Penerbit Gramedia Pustaka Utama.

Deddi dan Ayuningtyas Hertanti. 2010. Akuntansi Sektor Publik. Jakarta : Salemba Empat.

Hansen, Don R., dan Maryanne M. Mowen. 2006. Akuntansi Manajerial Edisi ke-8. Jakarta : Salemba Empat.

Harun. 2008. Reformasi Akuntansi dan Manajemen Sektor Publik. Jakarta : PT. Gramedia Pustaka Utama.

Ihyaul Ulum. 2009. Audit Sektor Publik : Suatu Pengantar. Jakarta : Penerbit Bumi Aksara.

Kuncoro, Mudrajad. 2009. Metode Riset untuk Bisnis \& Ekonomi. Edisi 3. Jakarta : Erlangga.

Kuswadi. 2005. Meningkatkan Laba Melalui Pendekatan Akuntansi Keuangan dan Akuntansi Biaya. Jakarta : Elex Media Komputindo.

M. Nafarin. 2004. Penganggaran Perusahaan. Jakarta : Salemba Empat.

Mardiasmo, 2002. Akuntansi Sektor Publik. Yogyakarta : Penerbit Andi.

Milton F. Usry dan Lawren H. Hammer dalam bukunya "Cost Accounting : planning \& Control" 2002

Mulyadi. 1995. Akuntansi Biaya. Yogyakarta : Penerbit FE UGM.

Mulyadi. 2008. Sistem Akuntansi. Jakarta : Salemba Empat.

Mulyadi. 2009. Akuntansi Biaya Edisi ke-5. Yogyakarta : UPP-STIM YKPN. 
Munandar. 2001. Budgeting, Perencanaan Kerja, Pengkoordinasian Kerja, Pengawasan Kerja. Depok : Universitas Indonesia Press.

Nur Fitri Farjil dan Lili Syafitri. 2013. Analisis Biaya Standar Dalam Rangka Pengendalian Biaya Produksi Pada PT. Pusri Palembang. Jurusan Ekonomi Sekolah Tinggi Ilmu Ekonomi MDP.

Robert N Anthony dan Roger H. Hermanson. 2001. Management Control System. Jakarta : Salemba Empat.

Rony A. Rusli. 2002. Manajemen Pemasaran Edisi Millenium 2. Jakarta : PT. Prenhalindo.

Santoso, Eko. 2011. Efisiensi dan Efektivitas Pengelolaan Keuangan Daerah di Kabupaten Ngawi. Surakarta : Fakultas Ekonomi, Universitas Sebelas Maret.

Siregar, Narumondang Bulan. 2003. Penyusunan Anggaran Perusahaan Sebagai Alat Manajemen dalam Pencapaian Tujuan. Fakultas Ekonomi Universitas Sumatera Utara.

Sondang. P. Siagian. 2001. Manajemen Sumber Daya Manusia. Jakarta : Bumi Aksara. 